AGRICULTURE AND BIOLOGY JOURNAL OF NORTH AMERICA

ISSN Print: 2151-7517, ISSN Online: 2151-7525, doi:10.5251/abjna.2011.2.5.806.817

(C) 2011, ScienceHuß, http://www.scihub.org/ABJNA

\title{
Effect of hot water treatment on quality and shelf-life of Keitt mango
}

\author{
Patrick Kumah, Francis Appiah and John K. Opoku-Debrah
}

\author{
Department of Horticulture, Faculty of Agriculture, College Of Agriculture And Natural \\ Resources, Kwame Nkrumah University Of Science \& Technology, Kumasi, Ghana. \\ patrickumah@yahoo.co.uk
}

\begin{abstract}
Mango anthracnose, a major postharvest disease, induces huge losses in mangoes and threatens mango export and consumption. The effectiveness of hot water treatment as a postharvest disease control measure on Keitt cultivar of mango was assessed over a 21-day storage period. Batches of fruits were subjected to various degrees of hot-water treatments at temperatures $48^{\circ} \mathrm{C}, 50^{\circ} \mathrm{C}, 52^{\circ} \mathrm{C}$ and control (tap-water $-33^{\circ} \mathrm{C}$ ) for various durations (each treatment had different time duration of 5 and 10 minutes). Fruits were stored at room temperature $\left(33^{\circ} \mathrm{C}\right)$. Hot water treatments at $52^{\circ} \mathrm{C} / 10 \mathrm{~min}, 52^{\circ} \mathrm{C} / 5 \mathrm{~min}, 50^{\circ} \mathrm{C} / 10 \mathrm{~min}$ and $50^{\circ} \mathrm{C} / 5 \mathrm{~min}$ proved to be effective in controlling anthracnose disease on Keitt fruits after 7 days in storage, whereas the control showed the highest incidence. Hot water treatment at $52^{\circ} \mathrm{C} / 5 \mathrm{minutes}$, however, proved to be the best treatment that controlled anthracnose in Keitt mango fruits after 21 days in storage. Hot water treatment did not significantly $(P>0.05)$ affect the fruit firmness, $\mathrm{pH}$ and total soluble solids.
\end{abstract}

Keywords: Keitt mango, anthracnose, hot water, fruit quality, shelf-life.

\section{INTRODUCTION}

World production of tropical fruit is estimated to have increased by nearly 20 million tonnes to reach 61.4 million tonnes in 2000 , of which developing countries account for some 98 percent. Mango is the dominant variety produced worldwide, followed by pineapples, papaya and avocado (FAO, 2001). Demand for mangoes is soaring, but erratic supplies and postharvest problems make it a difficult sector to service. In 2007, more than 33 million tonnes were produced worldwide, but only 850,000 tonnes were exported (CTA, 2008).

Ghana has experienced encouragingly significant growth in horticulture over the past decade. Growth in the sector for mango production and export has showed remarkable improvement. From a very modest beginning, engineered by Ghana Export Promotion Council (GEPC), which identified a niche in mango cultivation way back in the early nineties to the late nineties, the industry now has been able to break the 1,000 MT barrier, from a figure of $366 \mathrm{MT}$ in 2006 to 1,071 MT in 2007, and was already set to break the 2,000 MT barrier by the end of 2008 (Adade, 2008).

In spite of the growing worldwide demand for mango fruits, disease attacks coupled with their lower shelf- life poses a serious threat to the industry. The two most serious fungal diseases of mangoes are powdery mildew (Oidium mangiferae) and anthracnose (Collectrichum gloesporioides) both of which are prevalent in the wet season (Rice et al., 1993).

Unfortunately, domestic and international trade of fresh mangoes, have been limited by its high perishable nature and it's susceptibility to postharvest diseases, extremes of temperature and physical injury. The fruit may require from 3 to 9 days ripening and this short period seriously limits its commercialization in distant markets (Litz, 1997). Chemical treatments applied to the fruits have been reported to leave residues of the chemical on the fruits. This poses a significant health risk to the consumer and their use is very much restricted by regulatory bodies (Couey, 1989). However, heat treatment on mango fruits has been accepted worldwide as an ideal disease control treatment since it is environmentally safe and non-chemical.

The aim of this paper, therefore, was to determine the effects of postharvest hot water treatment on the quality and shelf-life of Keitt mango. 


\section{MATERIALS AND METHODS}

Plant Material and its Preparation: Mature green fruits of the 'Keitt' cultivar were carefully hand-picked from trees. 70 uniformly-sized fruits without any defects were selected for the experiment. These were washed of sap and other dirt and allowed to airdry. The experiment was carried out at the Department of Horticulture, Faculty of Agriculture, KNUST in Kumasi, Ghana.

Experimental Design: A Completely Randomized Design (CRD) with seven (7) treatments was used (Table 1). Each treatment was replicated ten (10) times.

Tables

Table 1: Treatment Combinations

\begin{tabular}{|c|c|c|}
\hline Treatm-ent & $\begin{array}{c}\text { Temperature }\left({ }^{\circ} \mathrm{C}\right) \text { of } \\
\text { hot water bath }\end{array}$ & $\begin{array}{c}\text { Time } \\
\text { ( minutes })\end{array}$ \\
\hline 1 & Control (ambient) & 0 \\
\hline 2 & 52 & 10 \\
\hline 3 & 52 & 5 \\
\hline 4 & 50 & 10 \\
\hline 5 & 50 & 5 \\
\hline 6 & 48 & 10 \\
\hline 7 & 48 & 5 \\
\hline
\end{tabular}

Parameters Analyzed: Ten fruits were selected randomly to represent each treatment. All the fruits with the exception of the control were dipped in hotwater at the pre-determined temperatures and times in a hot water bath. Each treatment was later assessed for total soluble solids (TSS), titratable acidity (TTA), $\mathrm{pH}$, weight loss, fruit firmness and macroscopic (visible) fungal growth on fruits.

\section{RESULTS AND DISCUSSION}

Total Soluble Solids of Fruits (TSS): Figure 1 shows that there was a general increasing trend in the total soluble solids (TSS) in the 'Keitt' mango fruits with days in storage. The control however recorded the lowest TSS value, 4 days after treatment and increased sharply up to day 10, after which TSS values increased at a decreasing rate until day 14. Similar trends were observed in treatments at $48^{\circ} \mathrm{C} / 10 \mathrm{~min}$ and $50^{\circ} \mathrm{C} / 5 \mathrm{~min}$. However TSS values for treatments at $52^{\circ} \mathrm{C} / 10 \mathrm{~min}, 52^{\circ} \mathrm{C} / 5 \mathrm{~min}$ and $48^{\circ} \mathrm{C} / 5 \mathrm{~min}$ showed a gradual increase in TSS values from days 4,10 to 14 in storage. Treatment at $50^{\circ} \mathrm{C} / 10 \mathrm{~min}$ however recorded a general decrease in TSS value from day 10 to 14, which was not observed in the other treatments. The observed differences were not significant ( $p>0.05)$.

\section{Figures}


Agric. Biol. J. N. Am., 2011, 2(5): 806-817

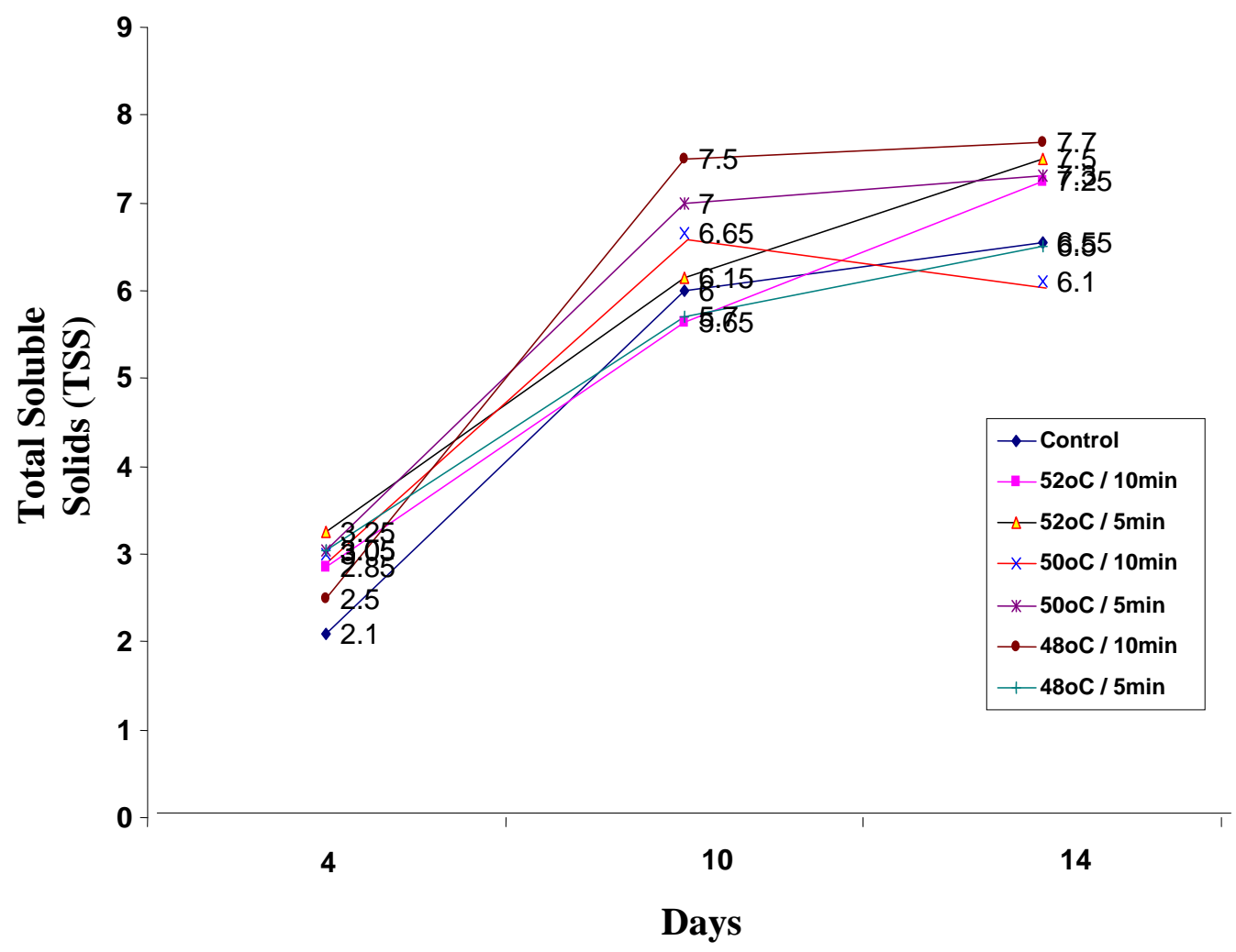

Fig 1: Effect of hot water treatments on TSS (\%) of 'keitt' mango fruits 4,10 \& 14 days after treatment.

This general increase in TSS observed was in accordance with similar reports by (Pantastico et al., 1984) who reported that total sugars and soluble solids increased as the 'Carabao' mango fruit ripened. Mendoza et al. (1972) also discovered that the soluble solids of mango increased with the onset of maturation.

There were very low TSS values recorded on the $4^{\text {th }}$ day (matured green) after treatment and this could be attributed to the fact that mango fruits at the mature green stage contained some accumulated starch which needed to be mobilized into sugars (Subramanyan et al., 1976). Generally there was steady increase in TSS value at day 10 (Fruits, halfripe), and day 14 (fruits, fully-ripe) after treatment.

Treatment $50^{\circ} \mathrm{C} / 10 \mathrm{~min}$ unfortunately gave unexplained decrease in TSS value on days 10 and 14 contrary to reports from various authors. This occurrence could probably be attributed to the fact that different fruits which were in the same treatments and were randomly picked for the same TSS determination on day 14 might not be of the same maturity or ripeness. This phenomenon is further explained by Schaffer et al., (1994) who indicated that fruits on the same tree may vary significantly in maturity levels due to prolonged or uneven flowering. The highest TSS value recorded for the 'Keitt' mangoes at $48^{\circ} \mathrm{C} / 10 \mathrm{~min}$ was 7.7 . This figure however does not agree with (Tridjaja et al., 1999) who indicated that Huramanis mango was best for consumption when the TSS content in the fruit was not less than 8.55 .

\section{Titratable Acidity of Fruits (TTA)}

From Figure 2 there was a general decreasing trend in the titratable acidity values (TTA). There was a very sharp decrease in TTA values for all the treatments from days 4 to 10 (when they had ripened), and further declined at a very slow rate as it approached day 14 . Though there were no significant differences ( $p>0.05)$ among all the treatments, $52^{\circ} \mathrm{C} / 10 \mathrm{~min}$ and $50^{\circ} \mathrm{C} / 10 \mathrm{~min}$ appeared to be decreasing gently because they had the lowest TTA on day 4. Kosiyachinda et al. (1984), explained that the reduction in acidity during ripening plays a great part in the acid:sugar balance and consequently in 
influencing the taste and flavour of the mango fruit, and that the predominant acids in the pulp was citric acid with some secondary acids such as malic and tartaric acid in varying proportions.

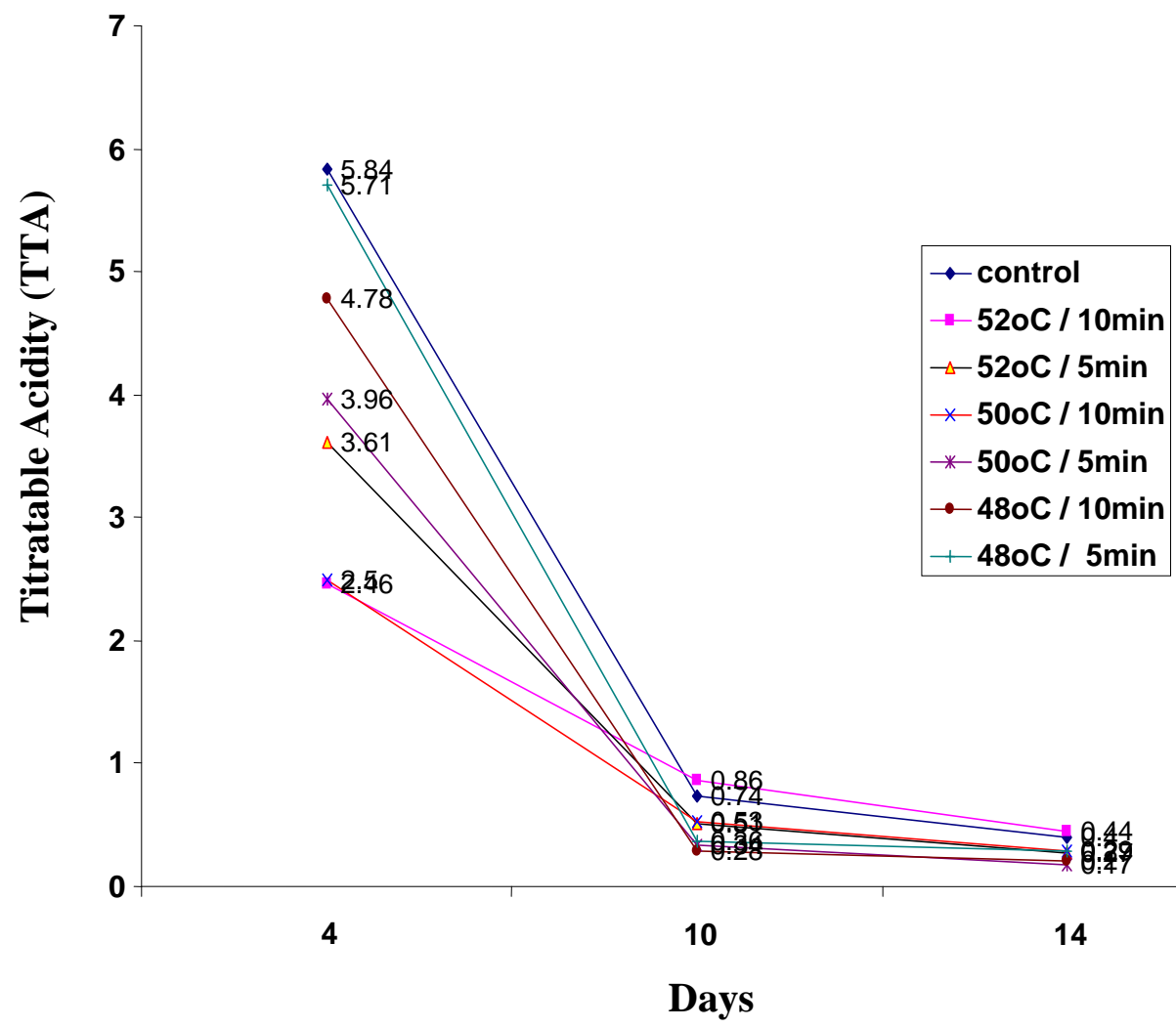

Fig. 2: Effect of hot water treatments on TTA (\%) of 'Keitt' mango fruits 4, 10 \& 14 after treatment.

There was an inverse relationship observed between the total soluble solids (TSS) and the titratable acidity (TTA) of the "Keitt" mango fruits throughout the experiment. Fruits with higher TSS would normally have lower TTA values (Lakshminarayana, 1980).

\section{pH of Fruits}

From Figure 3, a general increasing trend in the $\mathrm{pH}$ values for the 'Keitt' mango fruits can be observed. However treatments $50^{\circ} \mathrm{C} / 10 \mathrm{~m}$ and $48^{\circ} \mathrm{C} / 10 \mathrm{~m}$ increased in $\mathrm{pH}$ values sharply from day 4 to 10 and further increased at a decreasing rate till day 14 . Slightly different trends were observed between the control and treatments $52^{\circ} \mathrm{C} / 10 \mathrm{~m}, 52^{\circ} \mathrm{C} / 5 \mathrm{~m}, 48^{\circ} \mathrm{C} / 5 \mathrm{~m}$ and $50^{\circ} \mathrm{C} / 5 \mathrm{~m}$, where $\mathrm{pH}$ value increased at a decreasing rate from day 4 to 10 and further increased sharply till day 14 . However most treatments with the exception of the control appeared to show higher $\mathrm{pH}$ values by the end of day 14 (fruits fully-ripe). There were on significance in the observed differences $(p>0.05)$. 
Agric. Biol. J. N. Am., 2011, 2(5): 806-817

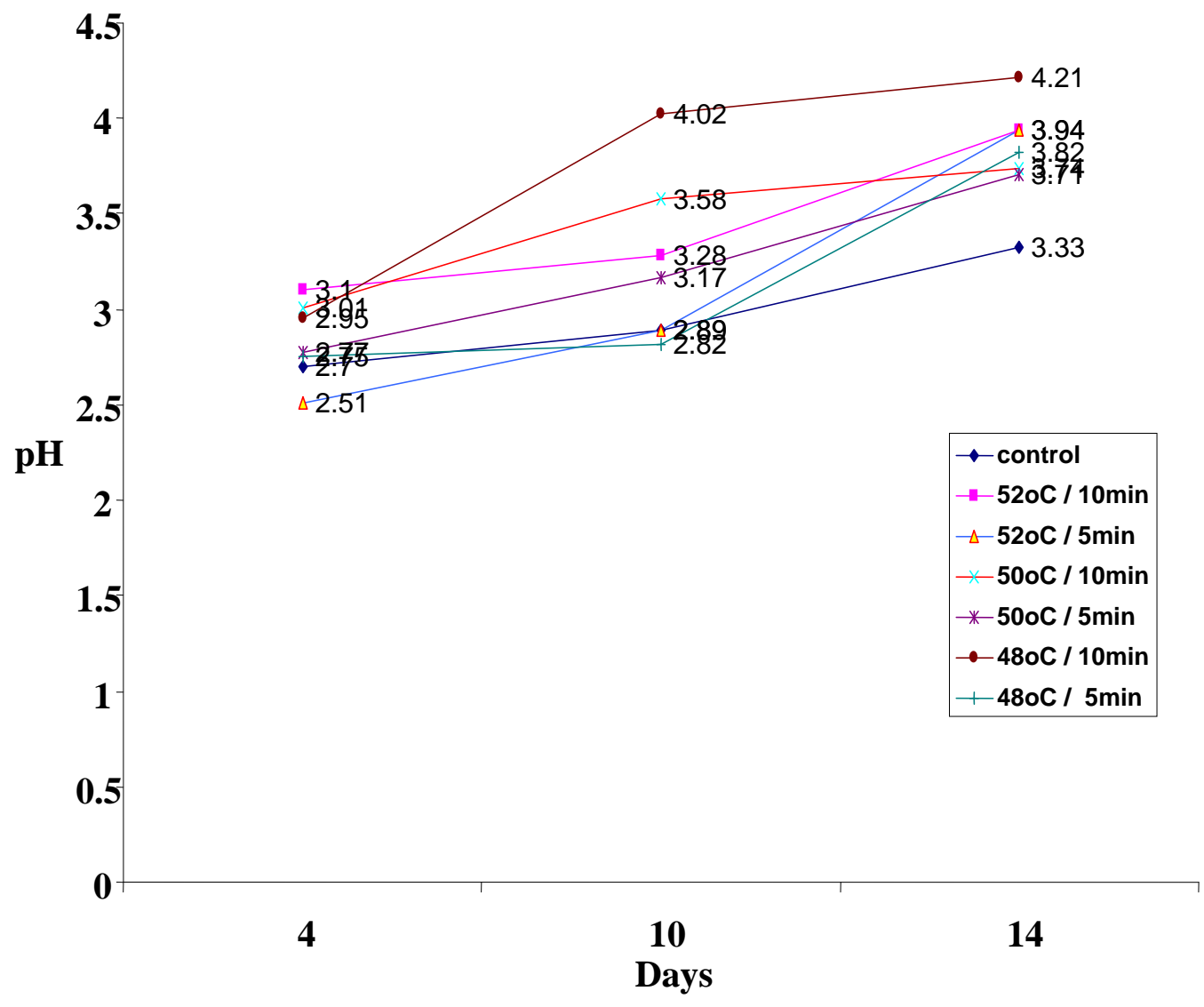

Fig. 3: Effect of hot water treatments on pH of 'Keitt' mango fruits 4, 10 and 14 days after treatment

This increasing trend is backed by (Johnson, 2000) who indicated that the $\mathrm{pH}$ values of fruit flesh increased with the onset of maturation till ripening. $\mathrm{pH}$ values obtained throughout the experiment with the exception of the control were similar to reports by Tridjaja and Mahendrat (1999) that Huramanis mangoes were best consumed when $\mathrm{pH}$ values were higher than 3.7. As titratable acidity of the fruits increased, $\mathrm{pH}$ decreased with fruit ripening.

Weight Loss in Fruits during Storage: Figure 4 shows a gradual increase in the cumulative weight loss in the 'Keitt' mango fruit after the $4^{\text {th }}$ day in storage and continued with rapid increasing trends till the $21^{\text {st }}$ day in storage. Treatments $52^{\circ} \mathrm{C} / 5 \mathrm{~min}$, $50^{\circ} \mathrm{C} / 10 \mathrm{~min}, 50^{\circ} \mathrm{C} / \mathrm{min}$ and $48^{\circ} \mathrm{C} / 10 \mathrm{~min}$ however showed very rapid increase in weight loss in comparison to the control at the onset of day 6 to the $20^{\text {th }}$ days in storage. These differences were however not significant $(p>0.05)$. The sharp rise in cumulative weight loss could be as a result of the high temperature and low relative humidity values obtained during the experiment $\left(25-31^{\circ} \mathrm{C}\right.$ and relative humidity of $70-80 \%$ ). 
Agric. Biol. J. N. Am., 2011, 2(5): 806-817

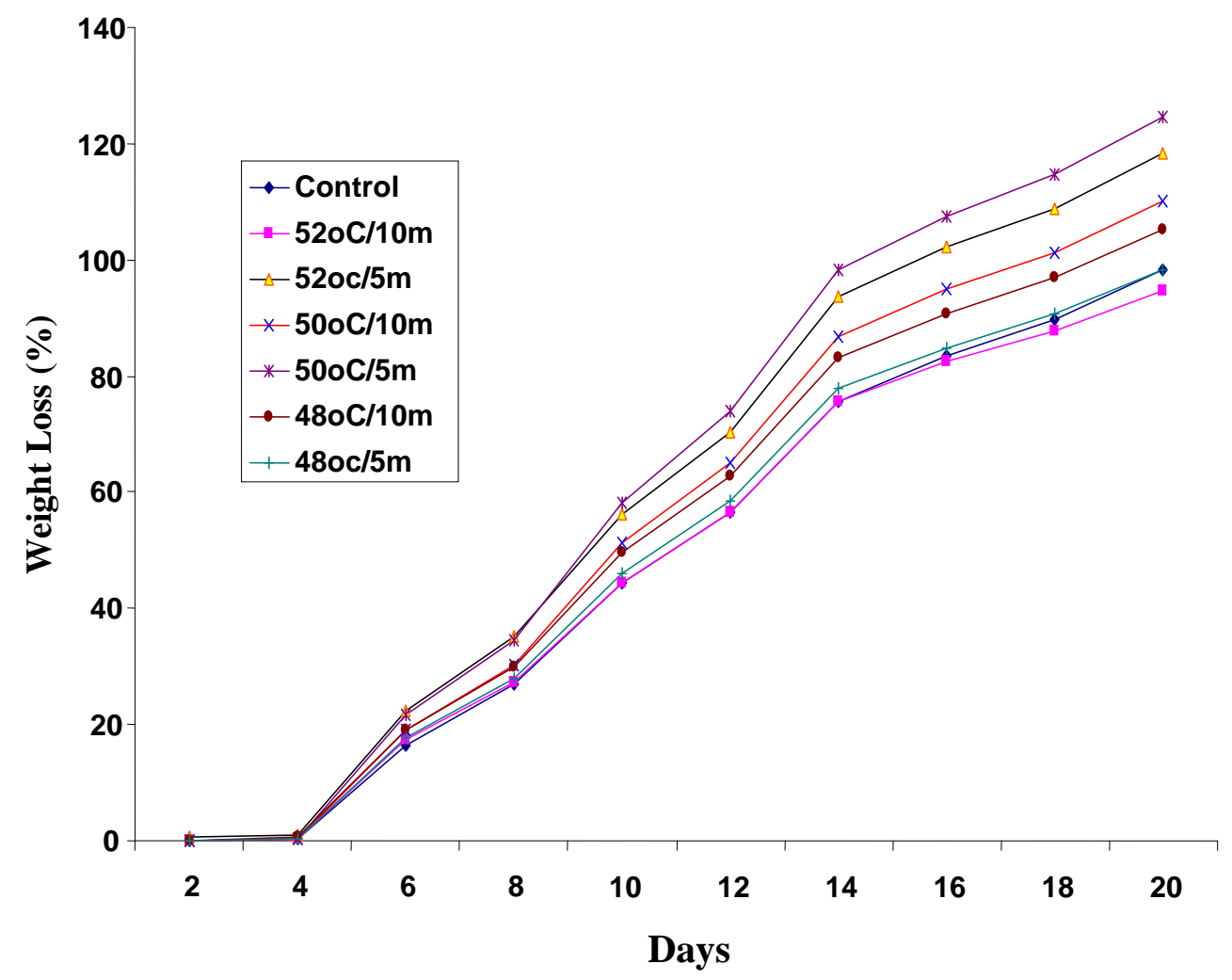

Fig.4: Percent Cumulative Loss in Fruit Weight over 21 days storage.

Fruit Firmness of 'Keitt' Mangoes after 10 and 14 Days in Storage: From Figure $5 a$ (i.e. firmness at day 10 ), treatment $48^{\circ} \mathrm{C} / 5 \mathrm{~min}$ was the most firm, followed by the control and treatment at $48^{\circ} \mathrm{C} / 10 \mathrm{~min}$ recording equal values in terms of fruit firmness. Treatment $50^{\circ} \mathrm{C} / 10 \mathrm{~min}$, gave the next highest score. The remaining 3 treatments gave equal scores, for fruit firmness and recorded the lowest values after 10 days in storage. By the $14^{\text {th }}$ day, all the fruits had become soft (Figure 5b). The general trend observed was that as fruits approached full ripening (day 14) there was reduction in fruit firmness. Ripening in many fruits is characterized by softening of the flesh. Softening is thought to be brought about amongst other factors by the concerted action of different cell wall hydrolases whose activity changes during ripening and alters the properties of many cell wall constituents, e.g. Pectin (Knee and Bartley, 1981). According to Pantastico et al. (1984), comprehensive studies on 'Carabao' mango showed that fruit firmness decreased abruptly early in the ripening period but continued to decrease with further ripening. 
Agric. Biol. J. N. Am., 2011, 2(5): 806-817

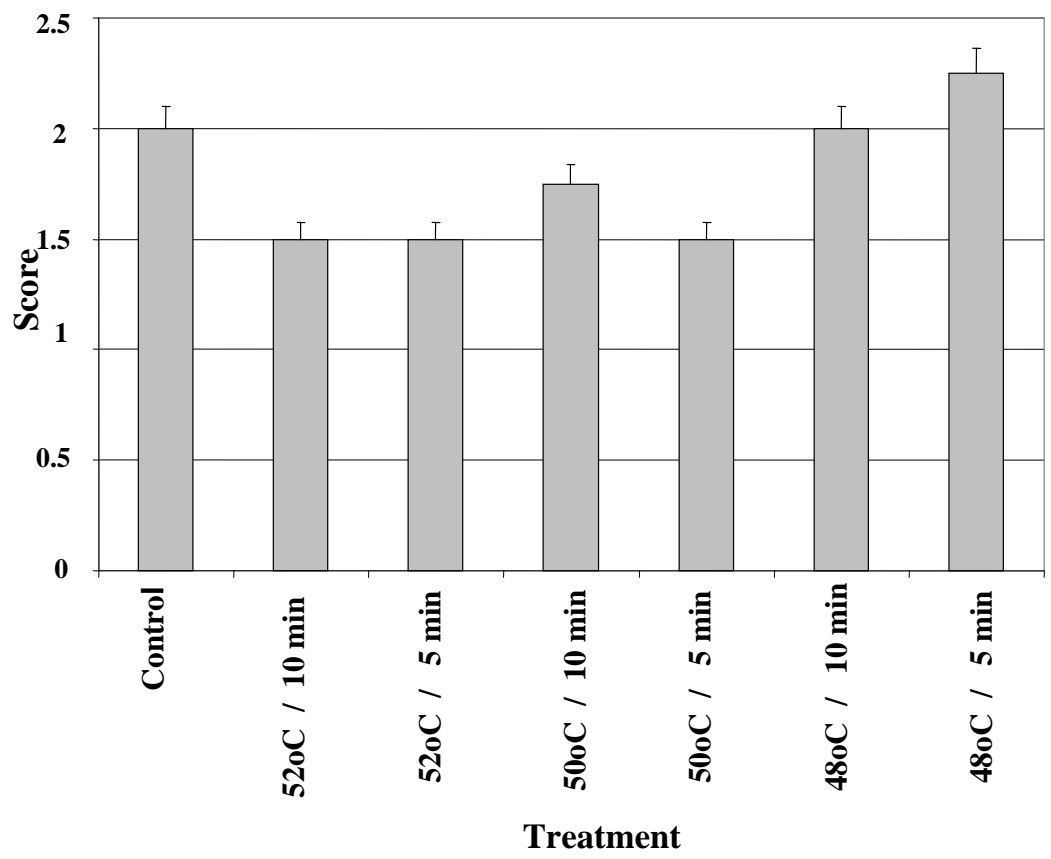

Fig.5a: Effect of hot water treatments on fruit firmness in 'Keitt' mangoes, 10 days after treatment.

Macroscopic (visible) Fungal Growth on 'Keitt' Mango Fruits 7, 14 and 21 Days after Storage

The main disease observed on individual fruits throughout the experimental period was anthracnose caused by a fungus (collectotrichum gloeospoiriodes). This was laboratory confirmed.
Figure 6a shows that the control treatment (where no hot water was applied) recorded the highest disease incidence of $40 \%$ with treatments $48^{\circ} \mathrm{C} / 10 \mathrm{~min}$ and $48^{\circ} \mathrm{C}$ recording the least values of $10 \%$. All the remaining treatments did not show any signs of anthracnose at the end of 7 days in storage. 
Agric. Biol. J. N. Am., 2011, 2(5): 806-817

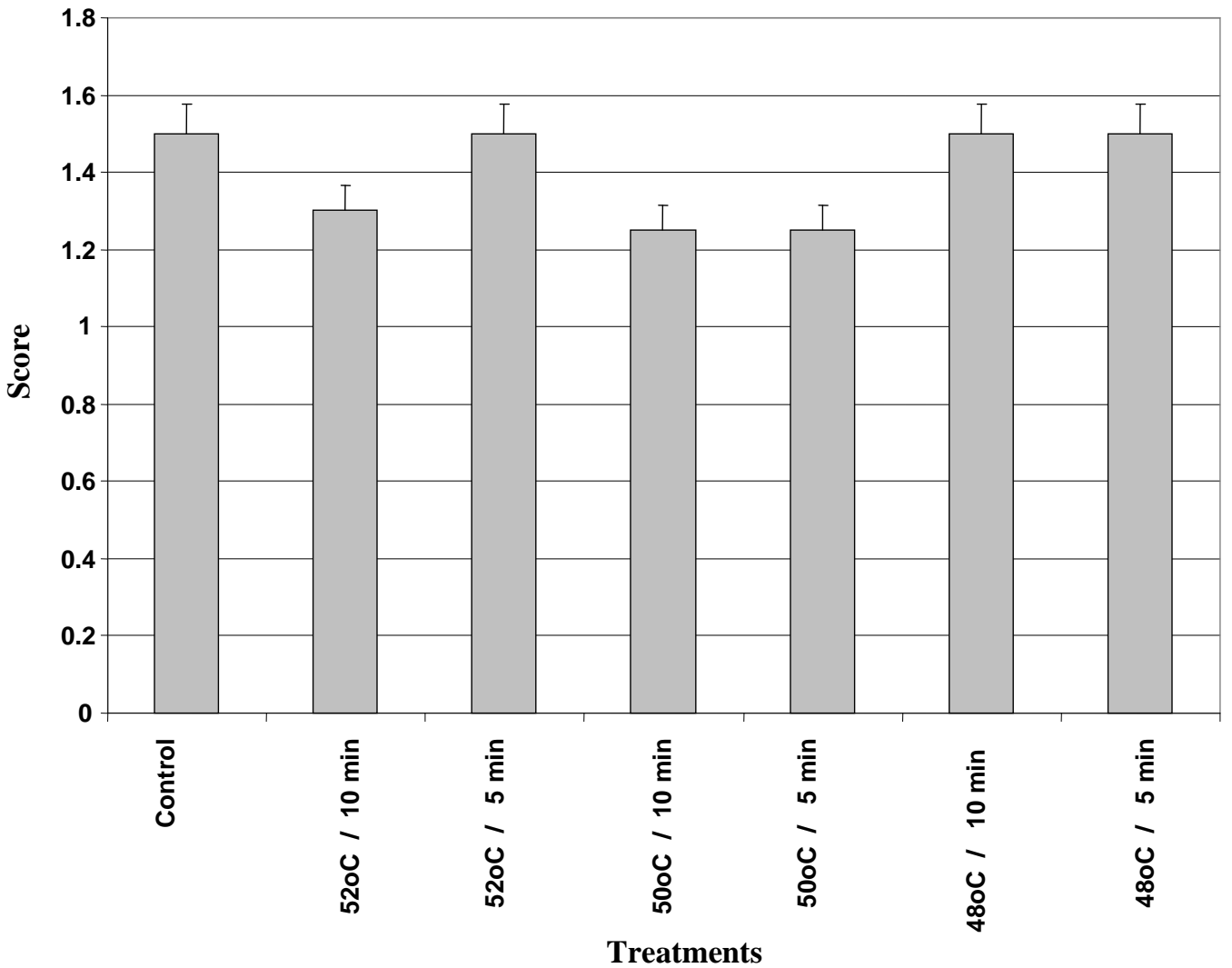

Fig.5b: Effect of hot water treatments on fruit firmness in 'Keitt' mangoes 14, days after treatment. 
Agric. Biol. J. N. Am., 2011, 2(5): 806-817

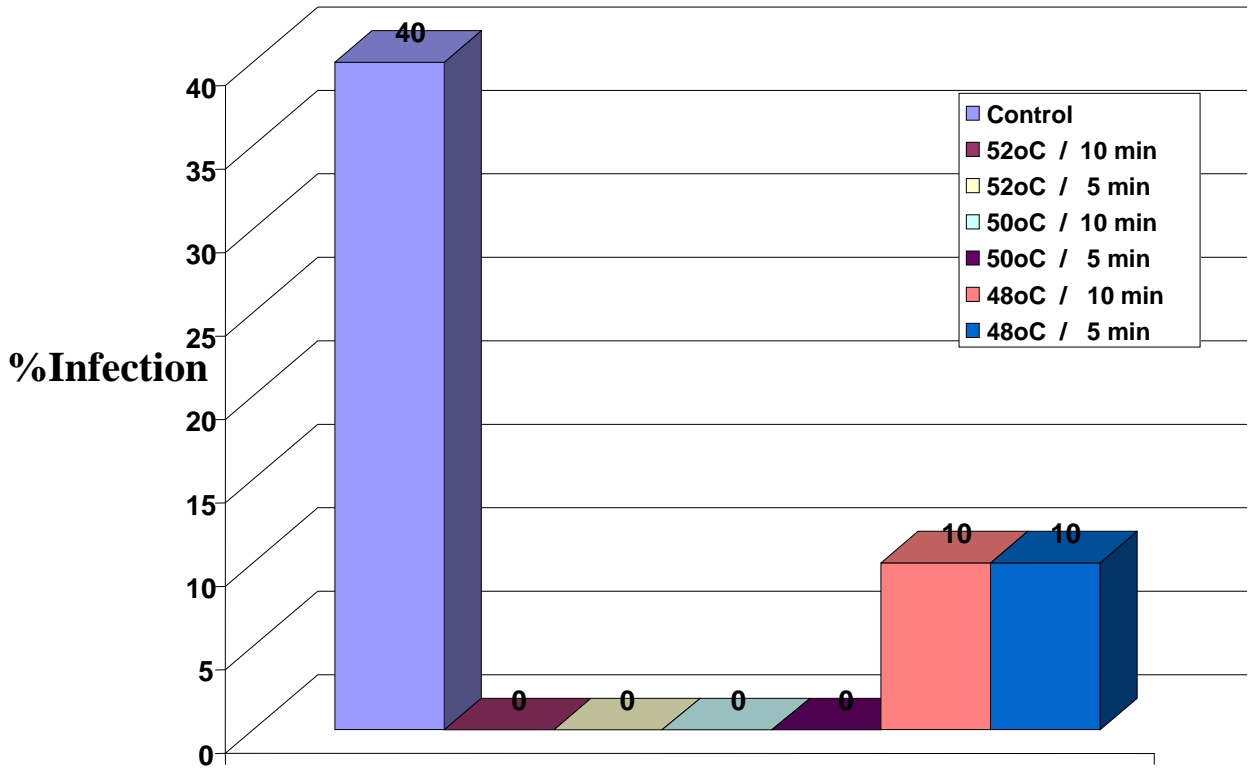

Treatment

Fig. 6a: Percentage of diseased of fruits 7 days after treatment

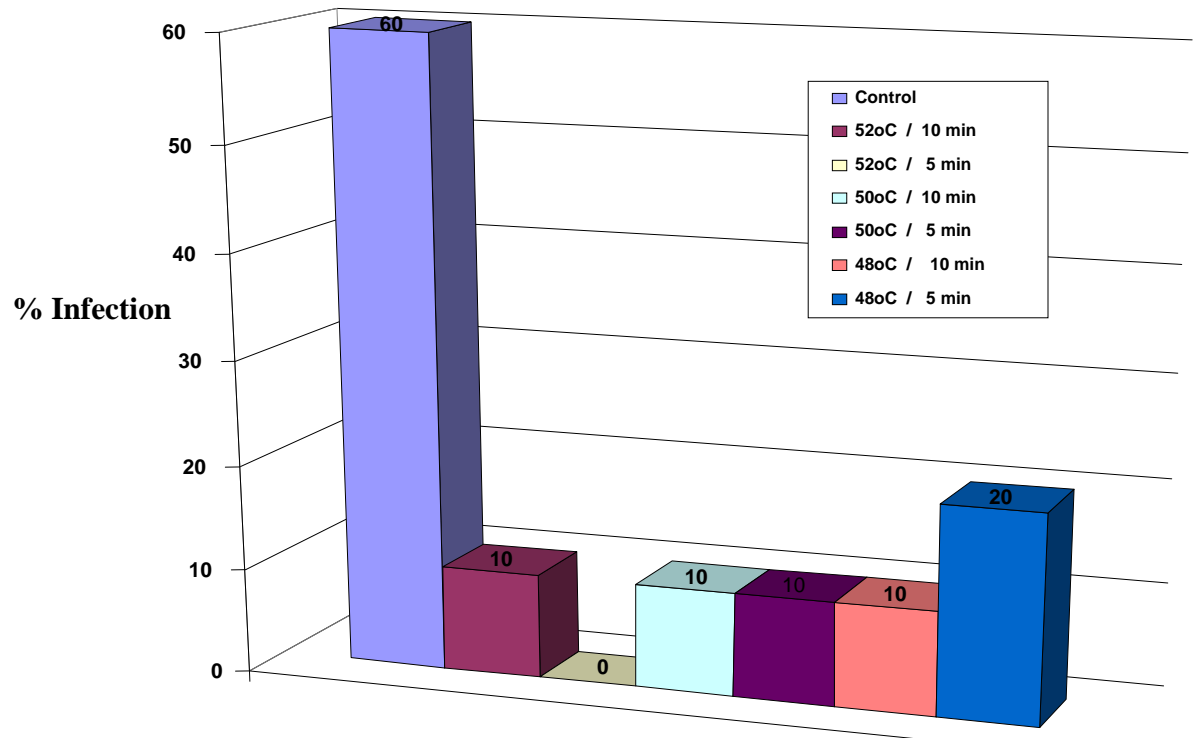

Treatments

Fig. 6c: Percentage of diseased fruits, 14 days after treatment. 
Figure.6b shows the same fruits on day 14. Results indicated that the control again recorded the highest percentage of infested fruits $(60 \%)$, with treatment $48^{\circ} \mathrm{C} / 5 \mathrm{~min}$ recording the $2^{\text {nd }}$ highest $(40 \%)$. Treatments $52^{\circ} \mathrm{C} / 10 \mathrm{~min}, 50^{\circ} \mathrm{C} / 10 \mathrm{~min}, 50^{\circ} \mathrm{C} / 5 \mathrm{~min}$ and $48^{\circ} \mathrm{C} / 5 \mathrm{~min}$ however recorded equal percentages of disease incidence of $10 \%$. Fruits in treatment $52^{\circ} \mathrm{C} / 5 \mathrm{~min}$ remarkably did not show any signs of anthracnose, after 14 days in storage.

From Figure 6c, the control (80\%) again recorded the highest incidence of disease infestation, followed by $48^{\circ} \mathrm{C} / 5 \mathrm{~min}(70 \%), 48^{\circ} \mathrm{C} / 10 \mathrm{~min}(60 \%)$, $50^{\circ} \mathrm{C} / \mathrm{min}(40 \%), 52^{\circ} \mathrm{C} / 10 \mathrm{~min}(20 \%)$ and $50^{\circ} \mathrm{C} / 10 \mathrm{~min}$ $(10 \%)$ respectively in that order. Treatment $52^{\circ} \mathrm{C} / 5 \mathrm{~min}$ again showed, remarkably, an absence of anthracnose infestation on individual fruits at the end of the 21 days in storage.
A wide range of microorganisms (fungi, bacteria, mycoplasma, etc.) affect horticultural produce (Sankat and Maharaj 1997). Fungal and bacterial infections on fruits results in loss in quality, which eventually reduces consumer acceptability and their economic value. Treatments $48^{\circ} \mathrm{C}$ at 10 and 5 minutes and the control proved very ineffective in the control of anthracnose in the 'Keitt' mango at 7 days in storage. The remaining treatments proved to be effective in controlling anthracnose. The most favourable treatment for controlling anthracnose throughout this study was hot water treatment at $52^{\circ} \mathrm{C} / 5 \mathrm{~min}$, similar observations were observed by Chapling, (1981) and Restituto and Bugante (1999) who found hot water treatment effective against fungal infection in fruits.

\section{Plates}

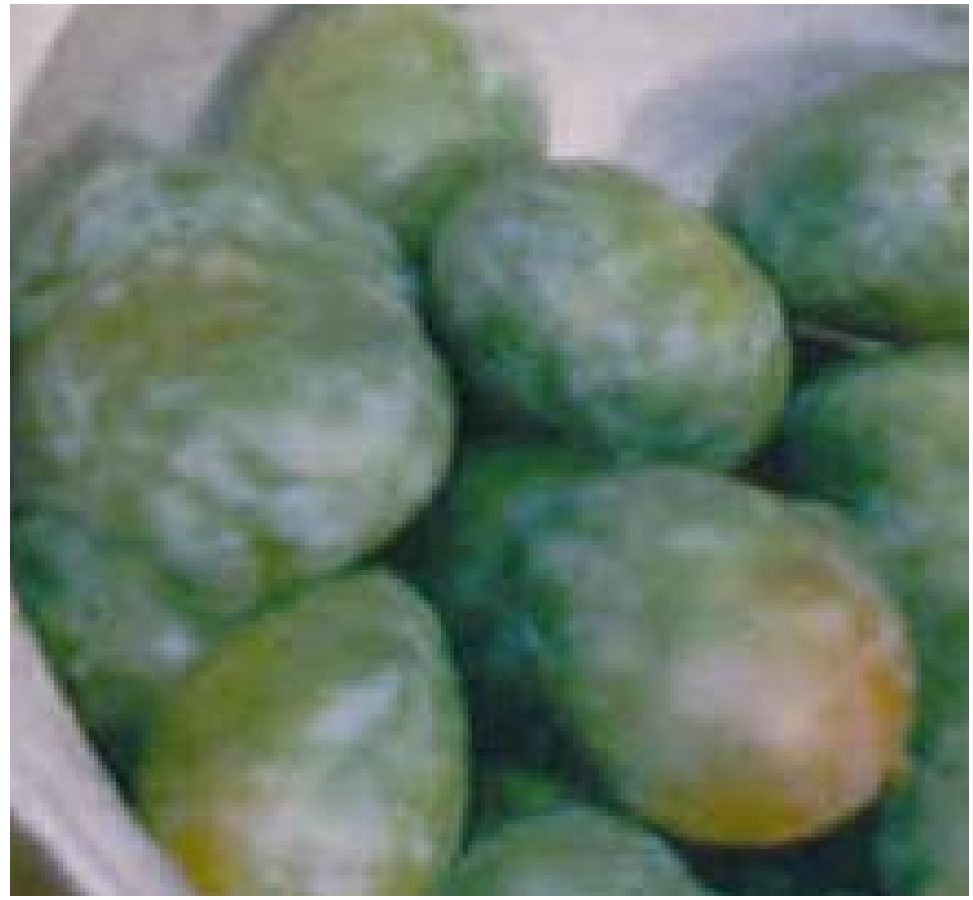

Plate 1. Harvested Keitt fruits. 
Agric. Biol. J. N. Am., 2011, 2(5): 806-817

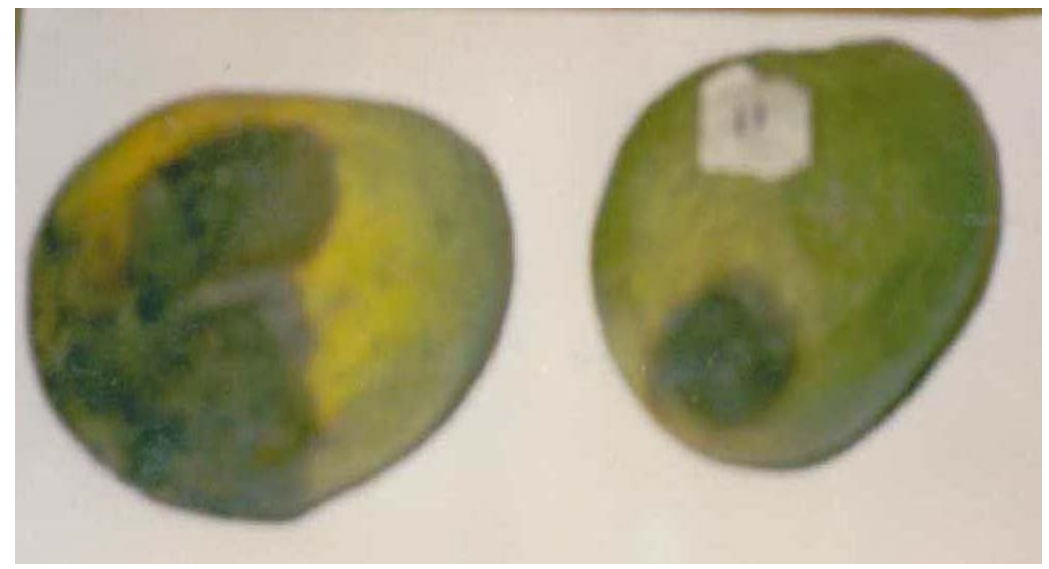

late 2. Keitt fruits showing signs of infection (Collectrichum gloesporioides).

\section{CONCLUSION}

The effectiveness of hot water immersion as a disease control on 'Keitt' mangoes was carried out in this study. In this experiment individual fruits were treated with hot water at varied temperature and times and evaluated over a 21 day storage period, at room temperatures of $25-31^{\circ} \mathrm{C}$ with a relative humidity of $70-80 \%$. The internal qualities such as $\mathrm{pH}$, TTA and TSS of the fruits were not affected by the treatment. However, most fruits were in best condition for eating with minimal disease incidence and ready-to-eat firmness when stored for about 14days. Hot water treatment at $52^{\circ} \mathrm{C}$ for 5 minutes could keep the fruits wholesome and free from anthracnose for the 21 days storage period.

Based on these findings, hot water treatment at $52^{\circ} \mathrm{C}$ for 5 minutes could be considered as an effective and environmentally friendly disease control measure against anthracnose in 'Keitt' mango fruits.

\section{REFERENCES}

Adade, R (2008). Ghana mango exports to Europe breaks the 1000ton mark. Ghana Fresh Produce. http://www.ghanafreshproduce.org/index.php?option=c om content\&task=view\&id=580\&ltemid=32

Chaplin, G.R. (1981). Postharvest Handling of mangoes, Tech. Bull. 55,Dept.Prim.Prod, North Terr. Australia.

Couey, M. H. (1989). Heat treatment for control of post harvest diseases and insect pests of fruits. Hortscience vol. 24(2): 198-202.
Couey, M.H. (1989). Heat treatment for control of post harvest diseases and insect pests of fruits. Hortscience vol. 24(2): 198-202

CTA. (2008). Mangoes? Spore.CTA.int http://spore.cta.int/index2.php?option_content\&do_pdf $=1 \& i d=814$

FAO (2001) Current market situation. Report of Intergovernmental group on bananas and tropical fruits. $2^{\text {nd }}$ Session of the Committee on commodity problems. Rome, p. 2.

Johnson, G.I. (2000). Quality Assurance In Agricultural Produce. ACIAR proceedings 100

Knee, M. and Bartley, I.M. (1981). Composition and metabolism of cell wall polysaccharides in ripening fruits. In: Friends, J. and Rhodes, M.J.C.(eds) Recent Advances in the Biotechnology of Fruits and Vegetables. Academic Press, New York, pp. 133-148.

Kosiyachinda, S., Lee, S.K. and Poernomo, S. (1984). Maturity indices for harvesting of mango. In: Mango: fruit development, postharvest physiology and marketing in ASEAN. (Mendoza, D.B. Jr and Wills, R.B.H., ed)., Malaysia, Association of South-East Asian Nations (ASEAN) Food Handling Bureau, 3338.

Lakshminarayana, A.S. (1980). Mango. In: S. Nagy and P.E. Shaw (ed.) Tropical and Subtropical Fruits Composition, Properties and Uses. AVI Publishing Inc., Westport, Connecticut. p. 185-201.

Litz, R. E. (1997). The Mango: Botany, Production and Uses. University Press, Cambridge, p. 5-12.

Mendoza, D.B., Javier, F.B. and Pantastico, E.B. (1972). Physico-chemical studies during growth and maturation of 'Carabao' mango. Animal Husbandry and Agriculture Journal, 7, 33-36. 
Agric. Biol. J. N. Am., 2011, 2(5): 806-817

Pantastico, E.B., Lam, P.F., Ketsa, S., Yuniarti and Kosittrakul, M., (1984). Postharvest physiology and storage of mango. In: Mango -fruit Development, Postharvest Physiology and Marketing in ASEAN. (Mendoza, D.B. Jr. and Wills, R.B.H. (eds)). ASEAN Food Handling Bureau, Kuala Lumpur, pp. 41-43.

Restituto Jr. and Bugante (1999). Determination of readiness to flower in the Carabao Mango, Enhancing Productivity of the Philippine mango Industry. Terminal Report. DOST, PCARRD, PCIERD, UPLB.

Rice, R. P., Rice, L. W and Tindall, H. D. (1993). Fruit and Vegetable production in Africa. Macmillan press Ltd, p. 78-81.

Sankat, C.A. and Maharaj, R. (1997). Papaya. In: Postharvest physiology and storage of tropical and sub-tropical fruits. Edited by Mitra. S. CAB International publications. Pp. 169-189.

Schaffer, B., Whiley, A.W. and crane, J.H. (1994). Mango. In: Hand book of Environmental and Physiology of Fruit Crops vol. II (Schaffre, B. and Andreson, P.C. (eds)). Sub-tropical and Tropical Crops. CRC Press, Boca Raton, pp. 165-197.

Subramanyan.H.,Gouri,S. and Krishnamrthy,S.(1976). Ripening behaviour of mango fruits graded on specific gravity basis. Journal of Food science and Technology 13, 84-86.

Tridjaja, N.O. and M.S. Mahendrat (1999). Food crops \& horticulture, Indonesia. Udayana University p 30-38 